\title{
Microbiological Properties of Stored Freeze Dried Cow Milk Cheese and Soy Cheese
}

\author{
${ }^{* 1}$ PAUL, T; ${ }^{2}$ ADEJUMO, BA; ${ }^{1}$ OKOSA, .I; ${ }^{1}$ CHIDINMA-EDEH, CE

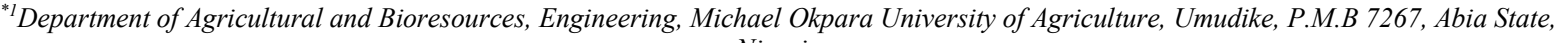 \\ Nigeria \\ ${ }^{2}$ Department of Agricultural and Bioresources, Engineering, Federal University of Technology, P.M.B 65, Minna, Niger State, Nigeria
}

*Corresponding Author Email: ptosin106@gmail.com

\begin{abstract}
The microbiological properties of stored freeze dried cow milk cheese and soy cheese were investigated. Cow milk cheese and soy milk cheese were prepared using appropriate standard procedures. The microbial qualities of the stored freeze dried samples were determined using standard methods as prescribed by Compendium of Methods for the Microbiological Examination of Foods and Bacteriological Analytical Manual. Data obtained were analyzed statistically to determine the effect of the packaging materials and storage duration on the microbial qualities of freeze dried cheese samples. Result of the microbial composition for the fresh cow milk and soy cheese for bacterial and fungi count are $3.00 \times 10^{3} \pm 0.01,2.54 \times 10^{6} \pm 0.05$ and $2.76 \times 10^{3} \pm 0.02,2.60 \times 10^{6} \pm 0.10$ while the result for the freeze dried cow milk and soy cheese before storage are $2.72 \times 10^{3} \pm 0.02,2.35 \times 10^{6} \pm 0.30$ and $2.54 \times 10^{3} \pm 0.03,2.38 \times 10^{6} \pm 0.50$. This indicates that all the packaging material types used have the ability to minimize the microbial growth of stored freeze dried cheese. Polythene film is recommended to be more suitable in terms of cost, availability, compactibility and weight.
\end{abstract}

DOI: https://dx.doi.org/10.4314/jasem.v24i3.23

Copyright: Copyright $(\subseteq) 2020$ Ovonramwen. This is an open access article distributed under the Creative Commons Attribution License (CCL), which permits unrestricted use, distribution, and reproduction in any medium, provided the original work is properly cited.

Dates: Received: 16 November 2019; Revised: 11 January 2020; Accepted: 22 February 2020

Keywords: cheese, freeze drying, microbial qualities, packaging materials.

The demand for dairy products in sub-Saharan Africa continues to increase with the overall growth rate in the consumption of milk and milk products being estimated at about $2.1 \%$ per annum. The growth in demand results from rapidly rising populations, urbanization and some increase in per capita income (Tofu, 2013). On the basis of population growth alone (about 15 million per annum) and a constant per capita consumption level of $27 \mathrm{~kg}$ the total requirement for dairy products would increase by 400 million $\mathrm{kg}$ each year (Tofu, 2013). An increase in per capita incomes would add to this demand and it is projected that total demand will grow at least by $4 \%$ per annum at current levels of production (Connor, 2003). Non-dairy ingredients find a critical role in synergy of dairy foods to enhance nutritional profile at the same time influencing the cost of the resultant product. Dramatic increases in the cost of milk have sent prices of milk ingredients skyrocketing - threatening the profitability of dairy and other food products (Bimbenet, 2008). In spite of remarkable increase in milk production, the milk and milk products are out of reach of the vulnerable groups of weaker section of society due to its high cost. This calls for development of low cost and healthy substitute for milk and milk products (Tofu, 2013). The search for a new and *Corresponding Author Email: ptosin106@gmail.com unconventional source of protein, carbohydrates, fat, vitamins, minerals and other health beneficial ingredients to meet the requirement of the everexpanding population is the dire need of the present day (Belewu, 2007).

The presence of soy milk in the market as an alternate to cow's milk is well established, the production process and preservation of these products is not well advanced which is responsible for its rapid deterioration. Food processing has inevitable consequences on the nutritional value of the food (Brennan and Day, 2006). It must be stressed that for the selective few that are able to afford animal milk, there is always an increasing concern about its fat and cholesterol contents. This factor has made vegetable milk to become an alternative source of milk. Soy cheese (a product from soymilk) accords advantages in terms of nutrition and health, since it contains no cholesterol or lactose and only small quantities of saturated fatty acids; in addition to its advantage of low cost. The basic reason for purposely processing milk into cheese is to preserve a perishable food and to convert it into a stable and storable product. It also expands the variety of food (Fabiyi, 2006). 
Cheese is perishable; it deteriorates few days after preparation. This is due to the high moisture contents and their inability to maintain their stable state. Keeping of cheese in stable form, with the ability to retain its actual nutrient, flavour, taste and colour as when prepared has remained a problem yet unsolved (Bonazzi, 2003). Soy cheese and cow milk cheese are commonly preserved in Nigeria by deep frying method. This process of frying under high heat and temperature affects the nutritional value of the cheese and also increase the calories contained in the cheese (Wang et al, 2012). Soy cheese and cow milk cheese get spoilt or rancid after some days; therefore there is a need to extend the shelf life by destroying or inhibiting micro-organisms and slowing down enzyme activity through freeze drying method. One of the ways by which cheese can be preserved is by freeze drying method, and this method can transform the cheeses into forms that have longer shelf life rather than keeping them in fresh forms which are perishable (Osho and Dashiell, 1998). Because of the absence of liquid water and the low temperature (approx. $20^{\circ} \mathrm{C}$ ) used during freeze drying operation, most of deterioration and microbiological reaction are stopped. In freeze dried products shrinkages are eliminated, minimum loss of flavour, aroma, vitamins, and near-perfect preservation results are obtained. Freeze drying of cheese will reduce the moisture to a level which will prolong its shelf life during storage, reduce colonization by microorganisms. The processing and packaging of soy cheese and cow milk cheese into forms that will reduce weight, volume, spoilage, enhance portability and extend shelf life will help to increase its availability all year round. The portability and availability of packaged soy cheese and cow milk cheese will increase its utilization, thereby enhancing the income of the farmers and producers. The objective of this work is to determine the microbiological properties of stored freeze dried cow milk cheese and soy cheese.

\section{MATERIALS AND METHODS}

One thousand five hundred grams $(1500 \mathrm{~g})$ of soy beans and three litres (31) of fresh cow milk was purchased at Kure Market Minna Niger State. Soy cheese and cow milk cheese used for this study was produced in the Crop Processing and Storage Laboratory of the Department of Agricultural and Bioresources Engineering, Federal University of Technology, Minna, Niger State, Nigeria.

Reagents and Instruments: The reagents used for this research study are distilled water, boric acid, mixed indicator, $\mathrm{n}$-hexane, and potassium hydroxide. The instrument used for this research study are sealing machine, petri-dishes, plate count jar, syringe, inoculation loop, agar plate and pre-sterilized container.

Methodology: The methodology used in processing the fresh whole milk in the production of cow milk cheese was prescribed by Amano (2013). The milk was kept to settle for about one hour then the top layer was skimmed off (high fat milk or cream) to reduce the fat content of the milk. The milk was heated to about $72^{\circ} \mathrm{C}$ to destroy most of the bacteria present and also to increase yield through precipitation of the whey proteins (Adetunji et al 2008), Lemon juice was used as coagulant which was diluted with an equal quantity of clean fresh water so that the lemon juice can be distributed uniformly. About $30 \mathrm{ml}$ of lemon juice per litre of milk was added and stirred carefully.

The curd precipitated almost immediately while stirring continued for about three minutes after adding the lemon juice and then the curd was allowed to settle. The curd was separated from the whey by draining through a muslin (cheese) cloth. While draining the whey, the curd was stirred to prevent excess matting (Adetunji et al., 2008). The curd was transferred to a container lined with muslin cloth. The curd was wrapped with the muslin cloth and a wooden follower was fitted neatly inside the mould to enable the curd to be pressed (Adetunji and Babalobi, 2012). The curd was pressed by placing metal weights on top. The cheese was removed from the mould and then cut into sizes of $2 \times 3 \mathrm{~cm}$ dimension and thickness of $0.2 \mathrm{~cm}$. It was taken to the laboratory and freeze dried. The freeze dried samples were then packaged in the different packaging materials for further analysis.

The soy cheese production from soy beans was carried out as prescribed by Connor, 2003. About 1000g of properly cleaned soy beans was soaked in water for 10-12 hours after which the soybeans was dehulled, grinded and then mixed with water. A sieve was used to separate the milk from the chaff in the mixture. The milk was pasteurized and allowed to cool while the coagulant was added to the milk to form curd. The curd was wrapped with the muslin cloth and pressed in a mould to remove the water present in the curd (Tofu, 2013). The hardened cheese was then cut into sizes of $2 \times 3 \mathrm{~cm}$ dimension and thickness of $0.2 \mathrm{~cm}$. The soy cheese was then taken to the laboratory and freeze dried. The freeze dried samples were then packaged in the packaging materials (Sterile tightly covered glass jar, sterile tightly covered plastic container and sterile polythene film) for microbiological properties analysis.

Experimental set up: The freshly prepared cow milk and soy milk cheese were cut into their various sizes 
which are produced from fresh cow milk and soybeans with lemon juice used as the coagulant. The cut cow milk cheese was divided into 6 portions of $100 \mathrm{~g}$ each while the cut soy cheese was also divided into 6 portions of $100 \mathrm{~g}$ each. With the initial properties of fresh cow milk cheese and soy cheese determined The samples were freeze dried in the lyophilizer for 3 hours at $-28^{0} \mathrm{C}$ with the compressor on, immediately after freezing; the freeze samples were subjected to low pressure with the vacuum switched on alongside with the compressor to start drying. During the drying process, water was seen boiling off or subliming from all the freeze cheeses at a lower pressure of 14 pascal and this was done for six hours for ten days. The microbial properties of the freeze dried samples were determined and $100 \mathrm{~g}$ of each sample were packaged in sterile tightly covered glass jar, sterile tightly covered plastic container and sterile polythene film while the samples left were the unpackaged samples which serves as the control sample. The experiment was carried out using a randomized block design of 3 packaging types and 3 months storage duration at 3 replicates $(3 \times 3 \times 3=27)$ for the cow milk and soy milk cheese samples. Samples were analyzed for their microbial qualities monthly during the storage period. Data obtained were analyzed statistically to determine the effect of the packaging materials and storage durations on the microbial properties of freeze dried cheese samples.

Microbial Qualities Determination: The microbial qualities of the fresh and freeze dried samples of cow milk and soy cheese were determined using standard methods as prescribed by Compendium of Methods for the Microbiological Examination of Foods, 2000 and Bacteriological Analytical Manual, 2002.

Determination of Bacteria Count in Cheese: For each dilution to be plated, aseptically $1 \mathrm{ml}$ sample suspension was transferred to 3 plates of Baird-parker agar, distributing $1 \mathrm{ml}$ of inoculum equitably to 3 plates. Inoculum was spread over the surface of the agar plate using sterile bent glass streaking rod. The plates are kept in upright position until inoculum was absorbed by agar (about 10minutes) on properly dried plates. The plates were inverted and incubated for 45 hours at $35^{\circ} \mathrm{C}$. Plates containing 20-200 colonies were selected. Colonies with typical appearance of bacterial are circular, smooth, convex, moist, 2-3mm in diameter on uncrowded plates, gray (jet black) frequently with light coloured (off white) margin. Colonies have gummy consistency when touched with inoculating needle.

Determination of Fungi Count in Cheese: The sample dilution containing fungi was placed in a kjeldahl flask. An alcoholic solution was used as indicator. Sufficient water was added to bring the total volume to $100 \mathrm{cc}$. The flask was connected to the condenser and the suction started. The mixture was brought to boiling and then the $\mathrm{MNO}_{2}$ was added but only after the vapours are condensing in the reflux condenser. The oxidizing agent was added drop by drop at a rate of not more than 1 per second until an excess has accumulated in the flask. When colloidal $\mathrm{MNO}_{2}$ was used, an actual excess was present for at least 10 minutes. The addition of the oxidizing agent was up to 10 minutes. This excess in turn was removed by one drop of $0.1 \mathrm{~N}$ of thiosulphate solution. The end point was finally adjusted with the dilute iodine solution in such a manner that one drop of this dilute iodine solution produces a clearly discernable change, but not a deep blue in the colourless solution.

Statistical Analysis: All experiments were carried out in three replicate. Data obtained was analyzed statistically using SPSS 20.0 statistical package to determine the analysis of variance (ANOVA) and the Duncan multiple range test to separate the means. The packaged soy milk and cow milk cheese used for the experiment are as shown in Plate 1:

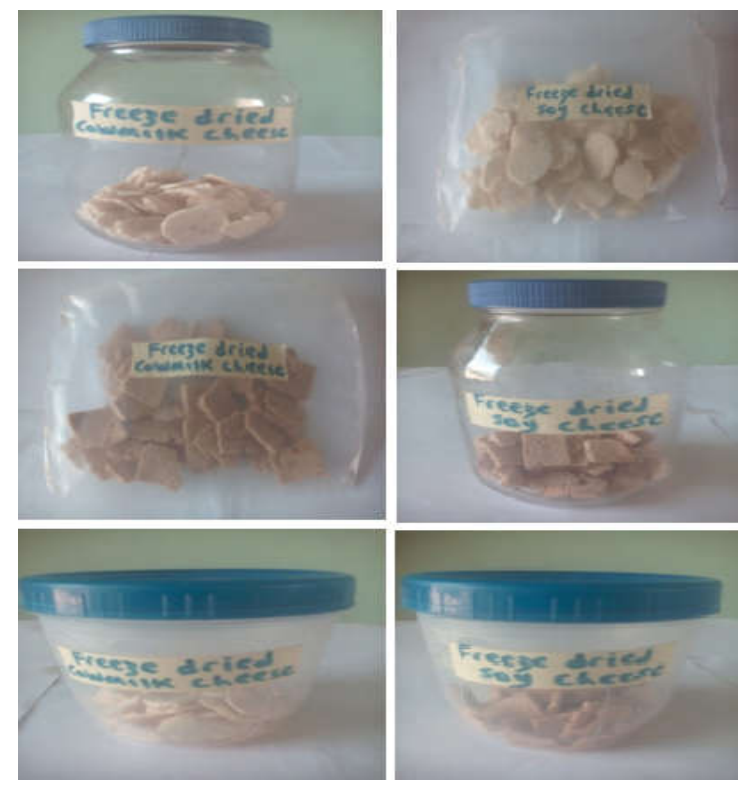

Plate 1: Samples of packaged freeze dried cow milk and soy cheese samples

\section{RESULTS AND DISCUSSION}

The microbial composition of stored freeze dried cow milk cheese: The results of the effect of freezing drying and storage duration on the microbial composition of freeze dried cow milk cheese and the ANOVA are presented in Table 1 and 2 while microbial composition of freeze dried soy cheese and the ANOVA are presented in Table 3 and 4. 
Table 1: Effect of freeze drying on the microbial composition of packaged freeze dried cow milk cheese

\begin{tabular}{llll}
\hline Sample & $\begin{array}{l}\text { Storage Duration } \\
\text { (Months) }\end{array}$ & Bacteria (CFU/g) & Fungi (CFU/g) \\
\hline Fresh Cow milk Cheese & & $3.00 \times 10^{3} \pm 0.01^{\mathrm{a}}$ & $54 \times 10^{3} \pm 0.05^{\mathrm{a}}$ \\
Freeze Dried Cow milk Cheese & & $2.72 \times 10^{3} \pm 0.02^{\mathrm{a}}$ & $2.35 \times 10^{3} \pm 0.30^{\mathrm{a}}$ \\
Sample Packaged in Glass Jar & 1 & $2.73 \times 10^{3} \pm 0.19^{\mathrm{a}}$ & $2.37 \times 10^{3} \pm 0.13^{\mathrm{a}}$ \\
& 2 & $2.75 \times 10^{3} \pm 0.02^{\mathrm{a}}$ & $2.40 \times 10^{3} \pm 0.02^{\mathrm{a}}$ \\
& 3 & $2.77 \times 10^{3} \pm 0.01^{\mathrm{a}}$ & $2.44 \times 10^{3} \pm 0.03^{\mathrm{a}}$ \\
Sample Packaged in Plastic jar & 1 & $2.75 \times 10^{3} \pm 0.20^{\mathrm{a}}$ & $2.38 \times 10^{3} \pm 0.02^{\mathrm{a}}$ \\
& 2 & $2.78 \times 10^{3} \pm 0.28^{\mathrm{a}}$ & $2.42 \times 10^{3} \pm 0.30^{\mathrm{a}}$ \\
& 3 & $2.80 \times 10^{3} \pm 0.01^{\mathrm{a}}$ & $2.44 \times 10^{3} \pm 0.02^{\mathrm{a}}$ \\
Sample Packaged & 1 & $2.76 \times 10^{3} \pm 0.03^{\mathrm{a}}$ & $2.42 \times 10^{3} \pm 0.01^{\mathrm{a}}$ \\
Polyethylene film & 2 & $2.80 \times 10^{3} \pm 0.01^{\mathrm{a}}$ & $2.45 \times 10^{3} \pm 0.04^{\mathrm{a}}$ \\
& 3 & $2.83 \times 10^{3} \pm 0.04^{\mathrm{a}}$ & $2.48 \times 10^{3} \pm 0.03^{\mathrm{a}}$ \\
Control Sample & 1 & $10.58 \times 10^{6} \pm 0.00^{\mathrm{b}}$ & $16.28 \times 10^{6} \pm 0.07^{\mathrm{b}}$ \\
& 2 & $23.90 \times 10^{6} \pm 0.04^{\mathrm{d}}$ & $32.15 \times 10^{6} \pm 0.12^{\mathrm{d}}$ \\
& 3 & $39.32 \times 10^{6} \pm 0.28^{\mathrm{e}}$ & $45.02 \times 10^{6} \pm 0.00^{\mathrm{e}}$
\end{tabular}

Value followed by same superscript alphabet are not significantly different at $(P<0.05)$ along the column. Values are Mean $\pm S E M$ of triplicate determination.

Table 2: Anova of the microbial composition of freeze dried cow milk cheese

\begin{tabular}{llrrrrr}
\hline & & $\begin{array}{l}\text { Sum } \\
\text { of Squares }\end{array}$ & df & $\begin{array}{l}\text { Mean } \\
\text { Square }\end{array}$ & F & Sig. \\
\hline Bacteria & Between Groups & 3669.280 & 5 & 733.856 & 3595.277 & .000 \\
& Within Groups & 2.449 & 12 & .204 & & \\
& Total & 3671.729 & 17 & & & \\
Fungi & Between Groups & 4155.932 & 5 & 831.186 & 12495.912 .000 \\
& Within Groups & .798 & 12 & .067 & & \\
& Total & 4156.730 & 17 & & & \\
\hline
\end{tabular}

Table 3: Effect of freeze drying on the microbial composition of packaged freeze dried soy cheese

\begin{tabular}{llll}
\hline Sample & $\begin{array}{l}\text { Storage Duration } \\
\text { (Months) }\end{array}$ & $\begin{array}{l}\text { Bacteria } \\
\text { (CFU/g) }\end{array}$ & Fungi (CFU/g) \\
\hline Fresh Soy Cheese & & $2.76 \times 10^{3} \pm 0.02^{\mathrm{a}}$ & $2.60 \times 10^{3} \pm 0.10^{\mathrm{a}}$ \\
Freeze Dried Soy & & $2.54 \times 10^{3} \pm 0.03^{\mathrm{a}}$ & $2.38 \times 10^{3} \pm 0.50^{\mathrm{a}}$ \\
Cheese & 1 & $2.55 \times 10^{3} \pm 0.15^{\mathrm{a}}$ & $2.39 \times 10^{3} \pm 0.00^{\mathrm{a}}$ \\
Sample Packaged in & 2 & $2.58 \times 10^{3} \pm 0.30^{\mathrm{a}}$ & $2.42 \times 10^{3} \pm 0.03^{\mathrm{a}}$ \\
Glass Jar & 3 & $2.60 \times 10^{3} \pm 0.04^{\mathrm{a}}$ & $2.45 \times 10^{3} \pm 0.02^{\mathrm{a}}$ \\
& 1 & $2.55 \times 10^{3} \pm 0.01^{\mathrm{a}}$ & $2.40 \times 10^{3} \pm 0.07^{\mathrm{a}}$ \\
Sample Packaged in & 2 & $2.59 \times 10^{3} \pm 0.00^{\mathrm{a}}$ & $2.43 \times 10^{3} \pm 0.04^{\mathrm{a}}$ \\
Plastic Container & 3 & $2.63 \times 10^{3} \pm 0.03^{\mathrm{a}}$ & $2.47 \times 10^{3} \pm 0.15^{\mathrm{a}}$ \\
& 1 & $2.58 \times 10^{3} \pm 0.02^{\mathrm{a}}$ & $2.42 \times 10^{3} \pm 0.30^{\mathrm{a}}$ \\
Sample Packaged in & 2 & $2.62 \times 10^{3} \pm 0.15^{\mathrm{a}}$ & $2.45 \times 10^{3} \pm 0.01^{\mathrm{a}}$ \\
Polyethylene film & 3 & $2.68 \times 10^{3} \pm 0.21^{\mathrm{a}}$ & $2.49 \times 10^{3} \pm 0.04^{\mathrm{a}}$ \\
& 1 & $14.18 \times 10^{6} \pm 0.05^{\mathrm{b}}$ & $16.10 \times 10^{6} \pm 0.03^{\mathrm{b}}$ \\
Control Sample & 2 & $26.27 \times 10^{6} \pm 0.01^{\mathrm{c}}$ & $30.35 \times 10^{6} \pm 0.17^{\mathrm{c}}$ \\
& 3 & $40.16 \times 10^{6} \pm 0.15^{\mathrm{d}}$ & $42.86 \times 10^{6} \pm 0.25^{\mathrm{d}}$
\end{tabular}

Value followed by same superscript alphabet are not significantly different at $(P<0.05)$ along the column. Values are Mean $\pm S E M$ of triplicate determination.

Table 4: ANOVA of the microbial composition of freeze dried soy cheese

\begin{tabular}{|c|c|c|c|c|c|c|}
\hline & & Sum of Squares & f & Mean Square & $\mathbf{F}$ & Sig. \\
\hline \multirow[t]{3}{*}{ Bacteria } & Between Groups & 3367.659 & 5 & 673.532 & \multirow[t]{3}{*}{4711.294} & \multirow[t]{3}{*}{.000} \\
\hline & Within Groups & 1.716 & 12 & .143 & & \\
\hline & Total & 3369.375 & 17 & & & \\
\hline \multirow[t]{3}{*}{ Fungi } & Between Groups & 4394.167 & 5 & 878.833 & \multirow[t]{3}{*}{5167.919} & \multirow[t]{3}{*}{.000} \\
\hline & Within Groups & 2.041 & 12 & .170 & & \\
\hline & Total & 4396.207 & 17 & & & \\
\hline
\end{tabular}

Effect of packaging materials and storage duration on the bacteria count of stored freeze dried cheese samples: The bacteria content observed in dairy products have been implicated in the spoilage of milk and its products (Gummalla and Hughes, 2004). Statistical analysis showed that freeze drying had 
significant effects $(\mathrm{P}<0.05)$ on the decrease in bacteria count in the freeze dried cheese samples (Table 2 and 4). The rather substantial decrease of bacteria count during freeze drying (Table 1 and 3) may be due to the rapid reduction in moisture content and the increase in temperature during freeze drying causing a deterioration of the bacterial count. The decrease in the bacteria counts of the freeze dried samples indicates a longer shelf life and minimum contamination. The bacteria count of the stored cheeses after the third month are $2.77 \times 10^{3}, 2.80 \times 10^{3}$ and $2.83 \times 10^{3}$ for samples in packaged in glass jar, plastic jar and polyethylene respectively. This result indicates that according to the current guidelines for microbiological quality of milk and dairy products (FAO/WHO, 2002), all the packaged cheeses are consumable while the unpackaged (control sample) with $39.32 \times 10^{6}$ is not consumable. However, there was no significant difference in the bacterial count of the stored cheese samples during the storage period. The type of packaging materials used and storage duration has no significant effect on the bacteria count of the stored cheese samples. The bacteria count of the unpackaged samples (control sample) increased significantly over the period of storage. Therefore, it is no more acceptable for consumption.

Effect of packaging materials and storage duration on the fungi count of stored freeze dried cheese samples: The fungi are a major spoilage organism of foods (Cogan, 2000). Statistical analysis shows that freeze drying had significant effect $(\mathrm{P}<0.05)$ on the decrease in fungi count in the freeze dried cheese samples (Table 2 and 4). The rather substantial decrease of fungi count during freeze drying may be due to the rapid reduction in moisture content and the increase in temperature during freeze drying causing a deterioration of the fungi count. The bacteria count of the stored cheeses after the third month are $2.60 \times 10^{3}$, $2.63 \times 10^{3}$ and $2.68 \times 10^{3}$ for samples in packaged in glass jar, plastic jar and polyethylene respectively. This result indicates that according to the current guidelines for microbiological quality of milk and dairy products (FAO/WHO, 2002), all the packaged cheeses are consumable while the unpackaged (control sample) with $40.16 \times 10^{6}$ is not consumable. The decrease in the fungi count in the freeze dried samples indicate a longer shelf life and minimum contamination. However, there was no significant difference in the fungi count of the stored cheese samples during the storage period (Table 1 and 3). Hence, the type of packaging materials used and storage duration has no significant effect on the fungi count of the stored cheese samples. The fungi count of the unpackaged samples (control sample) increased significantly over the period of storage. It is therefore not acceptable for consumption.

Conclusion: The bacterial and fungi count decreased significantly when freeze dried. Statistically, there was no significant difference in the microbial qualities of the stored cheese samples during the storage period irrespective of the packaging material used. This indicates that all the packaging materials used have the ability to minimize the microbial growth of stored freeze dried cheese. Polythene film is recommended to be more suitable in terms of cost, availability, compactibility and weight.

\section{REFERENCES}

Adetunji, AO; Babalobi, EA (2012). Microbial quality of wara, a southwestern Nigeria soft cheese. $J$. Dia. Res. 24:74-82.

Adetunji, VO; Ikheba, SA; Adedeji, AM; Alonge, DO (2008). Evaluation of the bacteria in milk products sold in Southern Nigeria. Nig. Vet. J. 24(3), 92-96.

Amano, EA (2013) Production of white soft cheese by rennet treatment. J. Dia. Res. 43, 112-118.

Bacteriological Analytical Manual (2002). $14^{\text {th }}$ Edition. Arlington. Ass. Off. Anal. Chem. W. D.C. p. 71-76.

Belewu, LH (2007). Preservation of cow milk cheese and perishable dairy products. S. A. J. Dai. Tech. 9: 127 - 133.

Bimbenet, KA (2008). Determination of Biogenic amine in feta cheese production. Food. Chem. 71: 259 - 266.

Bonazzi, HY (2003). Some properties of fresh and ripened herby cheese, a traditional variety produced in Turkey. Food Tech. Biotech. 42: 47 -50 .

Brennan, R.A and Day, R.L (2006). Chemical and physical methods. Standard method for the examination of Dairy products. $15^{\text {th }}$ edition. Ame. Pub. Health Ass. Balt. MD. 327 - 404.

Cogan T.M (2000). Cheese microbiology in P.F Fox, fundamentals of cheese science, Gaitheribury. Aspen publishers. Pp. 412-430.

Compendium of Methods for the Microbiological Examination of Food (2000). Split. Ed. W. D.C. p. 423-431. 
Connor, J.O (2003). Processing and production of soy cheese; improvement, production and uses. Caldwell, B.E, (Education), Ame. Soc. for Agro. U. S. A.

Fabiyi, W.E (2006). Analysis of cheese for histamine, tyramine, histidine, tyrosine and tryptophan. Journal of Diary Science. 68; 2845 - 2846.

FAO/WHO (2002). Milk and milk products. Joint Food and Agricultural Organization/ World Health Organization Food Standards Programme. CODEX Alim. Comm. 42.

Gummalla, S; Hughes, JE (2004). Over-expression of Lactobacillus Caseidehydroxy-Isocaproic Acid Dehydrogenase in Cheddar Cheese. App. Env. Micro. 70 (8) 43, 14-20.
Osho, SR; Dashiell, PM (1998). Influenced of pasteurised milk, raw milk and different ripening cultures on biogenic amine concentrations in semi soft cheeses during ripening. Euro. Food Res. Tech. 204: 265 - 272.

Tofu, JM (2013) Milk fermentation and nonfermented dairy products. Mod. Food Micro. Aspen press, Maryland. pp: 164-167.

Wang, SA; Michael, VO; Judy, KC (2012) Rational for Food Preservation. The Univ. Brit. Columbia. Lect. Notes. 